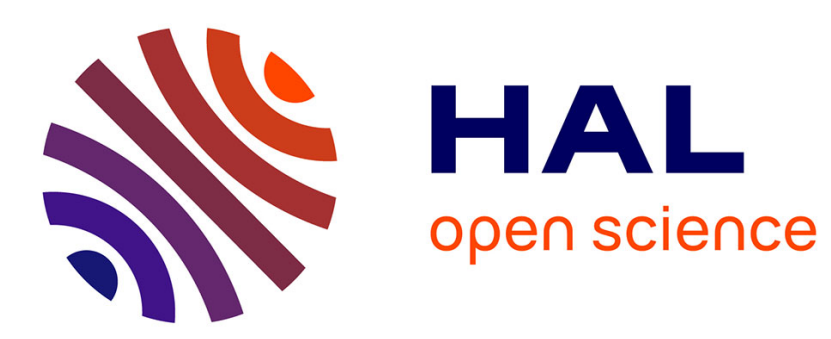

\title{
Linking Operational Business Intelligence with Value-Based Business Requirements
}

\author{
Tom Hänel, Carsten Felden
}

\section{To cite this version:}

Tom Hänel, Carsten Felden. Linking Operational Business Intelligence with Value-Based Business Requirements. 14th Conference on e-Business, e-Services and e-Society (I3E), Oct 2015, Delft, Netherlands. pp.147-159, 10.1007/978-3-319-25013-7_12 . hal-01448035

\section{HAL Id: hal-01448035 \\ https://hal.inria.fr/hal-01448035}

Submitted on 27 Jan 2017

HAL is a multi-disciplinary open access archive for the deposit and dissemination of scientific research documents, whether they are published or not. The documents may come from teaching and research institutions in France or abroad, or from public or private research centers.
L'archive ouverte pluridisciplinaire HAL, est destinée au dépôt et à la diffusion de documents scientifiques de niveau recherche, publiés ou non, émanant des établissements d'enseignement et de recherche français ou étrangers, des laboratoires publics ou privés.

\section{(c)(1)}

Distributed under a Creative Commons Attribution| 4.0 International License 


\title{
Linking Operational Business Intelligence with Value-based Business Requirements
}

\author{
Tom Hänel and Carsten Felden \\ TU Bergakademie Freiberg, Department of Management and Information Systems, Germany \\ \{tom.haenel, carsten.felden\}@bwl.tu-freiberg.de
}

\begin{abstract}
Operational business intelligence (OpBI) integrates data of business processes to analyse their performance in relation to organizational goals. The consequent decision-making concerns a timely recognition and execution of actions to maintain performant business processes. OpBI systems can be designed according to a firm-specific definition of requirements guided by considerations from business model, business process and information system perspective. However, there is no approach to link the design of OpBI jointly with characteristics of business models and business processes, yet. The paper uses therefore an action research method and proposes a business approach that combines $\mathrm{e}^{3}$ value with the work system framework to set up conceptual application designs for an OpBI-reliant decision support. We report on results of a long-term research project to demonstrate the development and application of our approach in four different business scenarios. The findings include implications towards a business-oriented application design of OpBI systems.
\end{abstract}

Keywords: Operational Business Intelligence, $\mathrm{e}^{3}$ value, work system, ADAPT.

\section{Introduction}

Organizations measure business processes using performance indicators in terms of time, quality, or cost [1]. The maintenance of performant business processes has to be closely linked to business strategy so that process improvements are valuable and lead to competitive advantages [2]. Management activities of process performance are thereby associated with IT to collect and analyse data about business processes [3]. Such IT capabilities need to be correspondent and compatible to business strategy, too, to avoid missing of expected performance results [2]. One possible concept to analyse business processes is $\mathrm{OpBI}$ dealing with an integration of daily business data [4]. This supports business operation's managers in gaining relevant knowledge to evaluate business process performances [5]. Management actions taken in consequence of an OpBI-reliant decision-making have to bring benefits to the manner of an organization creating value in its business environment. The paper's goal is therefore to investigate a linkage of OpBI with firm-specific business requirements.

The current discussion about OpBI provides no conceptual insights to consider business requirements for designing analytical systems in a particular case. For instance, the analysis requirements of insurance companies differ from issues of 
automotive suppliers from business perspective, although the technical system components can be quite similar. It is not obvious for application developers, how an OpBI system needs to be logically designed in order to maintain and improve performant business processes from a perspective of business operation's managers. A specification of OpBI systems can benefit from a value-based requirements engineering so that business value models initialize requirements for business processes and IT systems [6]. We investigate such a value-based requirements definition for OpBI systems and propose an approach to link the logical design of analytical databases with firm-specific business value models. The paper contributes with a development and application of our approach to the scientific discussion using participatory action research in context of four different organizations. This offers collaborative insights for research and practice to the discourse about business approaches so that operational management actions are beneficial for performant business processes.

Chapter 2 refines the problem of research and analyses related areas. The research method is presented in Chapter 3. Chapter 4 introduces our approach and Chapter 5 reports on its application during an action research project in four different business scenarios. Finally, a conclusion summarizes findings and further research activities.

\section{Status quo}

OpBI is understood as a decision support concept for business operation's managers to analyse business processes in favour of continuous improvements of process design and execution [4]. OpBI supports an identification of control actions based on timely relations between process performance and the status of goal achievement. [5]

\subsection{Problem refinement}

OpBI integrates data emerging in or flowing into IT systems during operational task fulfilment [4], [5]. From a technical viewpoint, OpBI systems can be equipped with IT providing business operation's managers access to manifold sources of information and analytical options in combination with high performance data processing. The discussion about Hadoop [7], cloud computing [8], combinations of transactional and analytical databases [9], or data virtualization techniques [10] points to a variety of technical options. However, these advancements will only lead to a successful decision support, if the performance analysis and action taking using an OpBI system is consistent to business goals and value creation processes. This requires a conceptual modelling of analytical requirements for OpBI systems in compliance with operational concerns of an organization. We conducted a literature review using the databases of Business Source Complete, IEEE, AIS, ACM, Emerald, and Science Direct to examine scientific publications according to MIS rankings [11]. The reviewed publications do not discuss a conceptual modelling of analytical requirements for a successful application of OpBI. A lack of discussion about conceptual modelling of operational information is evident, yet. 


\subsection{Related research areas}

OpBI addresses performance management (PM), BI, and business process management (BPM) [12]. PM structures business strategies and translates them into goals and ratios [13]. Process PM (PPM) monitors business processes using performance indicators [14]. The PPM concept is not limited to a specific IS support, but BPM or BI systems are discussed therein currently [1]. Monitoring business processes has a technical background coming from the BPM perspective [15]. BPM systems log transactions and events for execution tracking and process modelling [16]. The analysis of log data is limited, yet [17]. This extends especially in contexts of sophisticated processes with distributed tasks [18]. Due to an early stage of PM in the area of BPM, an integration of BI and BPM is taken into consideration [3]. From a BI perspective, the analysis of process data has a different focus. Business Process Intelligence supports the design and redesign of processes of an organization [19]. This affects a small range of users making strategic or tactical decisions. In contrast, process-centric BI concerns an integration of BI applications into process executions [20]. This affects the process performance due to accelerations and improvements of a process execution. BI provides analytical information to fulfil process related tasks. This differs from our OpBI understanding by using BI techniques for an analysis and control of business processes. Process-centric BI does not address a consideration of analytical information for an immediate measurement of process performance, an investigation of deviations, or a derivation of control actions.

\section{Research method}

We apply an action research method, because this has been used successfully to model business requirements and to align them with IT characteristics [6]. This is similar to our area of discourse by a conceptual modelling of OpBI systems. We extend the methodological knowledge and refer it to a participatory form of action research [21] - researchers and practitioners participate in a research process collectively. The collaboration allows a combination of modelling knowledge with practical experiences about analysing and controlling business processes. Action research supports a solution of immediate performance problems and a consolidation of conceptual knowledge on designing OpBI systems. Participatory action research has been successfully applied, too, in order to ensure that IT implementations result in business benefits [22]. Our intention is quite similar as we want to link the conceptual design of OpBI systems with value-based business requirements. Therefore, we deduce a practicability of participatory action research to deliver a business contribution in consequence of an OpBI-reliant decision-making. In a three-year research period, we performed an iterative and collaborative research process together with four organizations. Assumptions on designing OpBI systems were refined in cycles of diagnosis, action, evaluation, and reflective learning [21]. An approach to link value-based business models and OpBI systems emerged in consequence of our experiences. The approach builds upon the findings and multi-perspective view on requirements engineering of Gordijn and Akkermans [6]. 


\section{$4 \quad$ Linking value-based business models and OpBI systems}

Our approach consists of different activities resulting in $\mathrm{e}^{3}$ value models [6], a classification of business process requirements according to the work system framework [23] and ADAPT models [24]. Figure 1 classifies the elements of the approach into the perspectives of a value-based requirements engineering [6].

\begin{tabular}{|c|c|c|}
\hline Business model perspective & Business process perspective & OpBI system perspective \\
\hline$e^{3}$ value & Work system framework & \\
\hline & $A D A P T$ \\
\hline
\end{tabular}

Fig. 1. Elements of our approach

An $e^{3}$ value model describes an exchange of value objects between business actors in a commercial network. Such a network consists for instance of an organization anywhere in a value chain with its potential customers and suppliers. Business actors with an equal value proposition can be grouped to market segments. The value objects to be exchanged in a commercial network are trading items (products, services) in consideration of economic equivalents (money). Value activities model specific performance areas, in which an organization creates or adds value to yield profits. To dig deeper in the particular mechanisms of value activities, we bridge to a consideration of the business process perspective using the work system framework. Both approaches consider an internal and external view on organizations. Table 1 demonstrates the coincidence of $\mathrm{e}^{3}$ value and the work systems framework. A work system considers participants carrying out business processes by use of information and technology. These core elements of work system performance characterize together with general infrastructure components an insider's view on an organization's business value model. The performance output are products or services, which are the objects of value exchange with customers and the value chain environment. Strategic considerations influence the insider's and outsider's view regarding to work system performance. We use the elements of the work system framework and $\mathrm{e}^{3}$ value to deduce requirements for an analysis and control of value activities from an IT system perspective. Therefore, we use the ADAPT notation to develop logical data models as measurement and structuring instrument for value activity information in operational decision contexts. The work system and $\mathrm{e}^{3}$ value elements are assigned to dimensions and measures of an ADAPT model. The dimensions span a cube consisting of a set of measures having a clear reference to the value objects of the business model. The relationships of dimensions and measures follow the criteria of creating and exchanging values. 
Tab. 1. Mapping of $\mathrm{e}^{3}$ value and work system framework

\begin{tabular}{|c|l|l|}
\hline $\begin{array}{c}\text { View on } \\
\text { organizations }\end{array}$ & \multicolumn{1}{|c|}{$\begin{array}{c}\text { Elements of } e^{3} \text { value } \\
\text { External }\end{array}$} & $\begin{array}{l}\text { The whole } \mathrm{e}^{3} \text { value model } \\
\text { framework }\end{array}$ \\
\cline { 2 - 3 } & $\begin{array}{l}\text { Customers, external stakeholders, } \\
\text { partners, or suppliers modelled as market } \\
\text { segments or actors }\end{array}$ & Strategies \\
\cline { 2 - 3 } & Value exchanges, especially value objects & Products \& services \\
\hline \multirow{5}{*}{ Internal } & $\begin{array}{l}\text { Concerning organization performing } \\
\text { specific value activities }\end{array}$ & Infrastructure \\
\cline { 2 - 3 } & $\begin{array}{l}\text { Value activities representing areas of } \\
\text { performance }\end{array}$ & Business processes \\
\cline { 3 - 3 } & Participants \\
\cline { 3 - 3 } & & Information \\
\cline { 3 - 3 } & & Technologies \\
\hline
\end{tabular}

\section{$5 \quad$ Action research results}

We present the results of an action research project that was carried out from August 2012 to February 2014 in Germany in order to develop and apply our linking approach. Four organizations participated in three subsequent cycles of action research. The considered organizations were a machine tool manufacturer, a service provider for IT and communication (ICT) products, a hydraulics engineering company, and an insurance agency. The first cycle refers to activities of interaction, application, and reflection from a business models perspective and results in $\mathrm{e}^{3}$ value models. The outcome of the second research cycle is represented by a work system classification. The third cycle of action research lead to ADAPT models for an OpBI database design. Illustrations of $\mathrm{e}^{3}$ value and ADAPT models are presented only in context of the machine tool manufacturer due to the limited space of the paper.

\subsection{Research cycle 1: Creation of value-based business models}

Machine tool manufacturer. The organization modernizes gear hobbing machines. Equipment upgrades happen according to individual customer orders with negotiated budgets, period and quality requirements. The value activities (cf. Figure 2) include a deployment of new components, such as control units or milling heads. Once the transfer of a customer's machine happens, a dismantling in machine components takes place. Specific and standard parts are cleaned and listed. The employees record geometrical data and take pictures in case of incomplete drawings. Decisions about a rework or a remanufacturing depend on the machine state. Finally, the execution of the re-assembling happens. Disturbance variables are the individuality and the unpredictability of the machines and their states. Different projects and suppliers must be coordinated in consideration of compliance in time and cost conditions. 


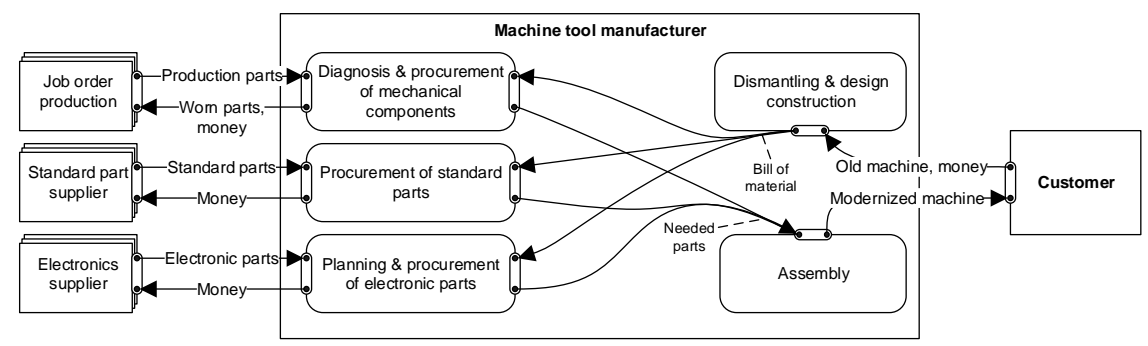

Fig. 2. $e^{3}$ value model of a machine tool manufacturer

ICT service provider. Logistical services are performed to distribute ICT products from different brands through different channels. The product procurement involves manufacturers or network operators. Devices are customized according to specified requirements, e.g. exchanges of electronic parts. A recovery resets returned devices to factory settings and performs functional checks. If, necessary, a partner company repairs defect devices. Final products are completed and packaged for shipment. Disturbance variables are fluctuating throughput quantities, a changing staff, heterogeneous products and fast price slumps. Especially velocity and cost efficiency are important control aspects.

Hydraulics engineering company. The organization produces hydraulic or pneumatic cylinders and job orders. The customer segment includes industrial trucks, rail vehicles, agricultural machinery, printing presses, or injection moulding machines. The manufacturing concerns activities of metal processing like milling, drilling, turning, welding, or laundry. The assembly of finished products includes functional tests, colouring, and shipment. A quality control records complaints during production and decides for rework, sorting, claim, or scrap. Disturbance variables are order withdrawals, missing materials, troubles of external manufacturers, unavailable labours, or malfunctions of e.g. automatic welders or CNC machining centres. Such disturbances lead to delays of planning cycles. Considering monthly value creation targets should overcome the uncertainties. This means that alternative outputs have to compensate adverse circumstances, if, for example, an order is cancelled.

Insurance agency. Insurance products are distributed on behalf of an insurance group. The strategic goals of the insurance group concern high premium customer portfolios, optimized trading results, and excellent business processes. The insurance agency has to fulfil the goals by efficient service actions. A planning and scheduling of sales conversations concludes insurance contracts for different products with commercial or individual customers. The agency coordinates, supervises and settles customer claims. Disturbance variables are manifold. Expiring insurance contracts or premature dismissals reduce the number of customers. Failing approaches to agree conversation dates or cancellations counteract attempts to sustain or increase sales revenues. Delays or contradicting information impair the handling of claims due to a missing communication between different contact points, which record claims or requests. 


\subsection{Research cycle 2: Classification of business process characteristics}

Table 2 classifies the studied organizations into the work system framework. The processes need to be dynamic with a certain variability. The business processes are deterministic and repeatable, while the performance results differ for changing situations. The tasks depend on knowledge and experience of the employees executing, guiding, and instructing operational activities. The information refers to reference inputs, control indicators, resources, products, or stakeholders.

Tab. 2. Classification of case studies into work system framework

\begin{tabular}{|c|c|c|c|c|}
\hline & $\begin{array}{l}\text { Insurance } \\
\text { Agency }\end{array}$ & $\begin{array}{l}\text { Hydraulics } \\
\text { engineer }\end{array}$ & $\begin{array}{l}\text { Machine tool } \\
\text { manufacturer }\end{array}$ & $\begin{array}{l}\text { ICT service } \\
\text { provider }\end{array}$ \\
\hline $\begin{array}{l}\text { Processes and } \\
\text { activities }\end{array}$ & $\begin{array}{l}\text { Consulting, claim } \\
\text { settlement, sales } \\
\text { conversations }\end{array}$ & $\begin{array}{l}\text { Manufacturing, } \\
\text { quality control, } \\
\text { assembly }\end{array}$ & $\begin{array}{l}\text { Dismantling, } \\
\text { cleaning, rework, } \\
\text { assembly }\end{array}$ & $\begin{array}{l}\text { Customization, } \\
\text { recovery, } \\
\text { shipment }\end{array}$ \\
\hline Participants & $\begin{array}{l}\text { Senior manager, } \\
\text { back office, sales } \\
\text { representatives, } \\
\text { call centre agents }\end{array}$ & $\begin{array}{l}\text { Engineers, } \\
\text { assemblers, } \\
\text { operators, } \\
\text { supervisors }\end{array}$ & $\begin{array}{l}\text { Project teams with } \\
\text { assemblers, } \\
\text { engineers, project } \\
\text { leader }\end{array}$ & $\begin{array}{l}\text { Shop floor and } \\
\text { temporary staff, } \\
\text { supervisors and } \\
\text { unit manager }\end{array}$ \\
\hline Information & $\begin{array}{l}\text { Customer records, } \\
\text { availability and } \\
\text { history, cross } \\
\text { selling ratio, } \\
\text { claims, expense } \\
\text { ratios, premium } \\
\text { targets and } \\
\text { incomes, contracts }\end{array}$ & $\begin{array}{l}\text { Time data, design } \\
\text { drawings, bill of } \\
\text { materials, defect } \\
\text { reports, article } \\
\text { data, consumption } \\
\text { rates, target/ actual } \\
\text { quantities, expense } \\
\text { ratios, added value }\end{array}$ & $\begin{array}{l}\text { Time data, design } \\
\text { drawings, } \\
\text { geometrical data, } \\
\text { bill of materials, } \\
\text { orders, delivery } \\
\text { dates, quality } \\
\text { indications, } \\
\text { budged limits }\end{array}$ & $\begin{array}{l}\text { Time data, expense } \\
\text { ratios, target } \\
\text { quantities, delivery } \\
\text { dates, article } \\
\text { master data, } \\
\text { consumption rates, } \\
\text { actual quantities, } \\
\text { defective products }\end{array}$ \\
\hline Technologies & $\begin{array}{l}\text { Platform to prepare } \\
\text { and manage } \\
\text { proposals, policies } \\
\text { issues, portfolios } \\
\text { and accountings }\end{array}$ & $\begin{array}{l}\text { ERP, Product data } \\
\text { management, } \\
\text { Machine data } \\
\text { acquisition, Time } \\
\text { keeping }\end{array}$ & $\begin{array}{l}\text { ERP, Product data } \\
\text { management, Time } \\
\text { keeping, Project } \\
\text { management } \\
\text { system, }\end{array}$ & $\begin{array}{l}\text { ERP, Warehouse } \\
\text { management } \\
\text { system, Machine } \\
\text { data acquisition, } \\
\text { Time keeping }\end{array}$ \\
\hline Infrastructure & $\begin{array}{l}\text { Office equipment } \\
\text { with interfaces to } \\
\text { the insurance } \\
\text { group, four } \\
\text { employees }\end{array}$ & $\begin{array}{l}\text { Office and } \\
\text { production } \\
\text { equipment, } 100 \\
\text { employees, staff } \\
\text { involvement }\end{array}$ & $\begin{array}{l}\text { Office and } \\
\text { production } \\
\text { equipment, } 70 \\
\text { employees, project } \\
\text { hierarchies }\end{array}$ & $\begin{array}{l}\text { Office and } \\
\text { logistics } \\
\text { equipment, 1,500 } \\
\text { employees, flat } \\
\text { hierarchies }\end{array}$ \\
\hline Strategies & $\begin{array}{l}\text { Increase of } \\
\text { shareholder values, } \\
\text { high premium } \\
\text { customers }\end{array}$ & $\begin{array}{l}\text { High quality, } \\
\text { flexibility and } \\
\text { velocity, reliability } \\
\text { to customers }\end{array}$ & $\begin{array}{l}\text { Specialization, } \\
\text { focus on customer, } \\
\text { undercutting of } \\
\text { original prices }\end{array}$ & $\begin{array}{l}\text { Diversification of } \\
\text { sales, service and } \\
\text { repair, high quality } \\
\text { at low costs }\end{array}$ \\
\hline Environment & $\begin{array}{l}\text { Insurance group, } \\
\text { financial markets, } \\
\text { changing } \\
\text { commercial and } \\
\text { legal conditions, } \\
\text { regional sales area }\end{array}$ & $\begin{array}{l}\text { Supplier relations, } \\
\text { high competitive } \\
\text { pressure, growing } \\
\text { international } \\
\text { market }\end{array}$ & $\begin{array}{l}\text { Supplier relations, } \\
\text { high competitive } \\
\text { pressure, deadline } \\
\text { and cost pressure, } \\
\text { international } \\
\text { market }\end{array}$ & $\begin{array}{l}\text { Supplier and } \\
\text { partner relations, } \\
\text { international } \\
\text { market, varying } \\
\text { order situations, } \\
\text { fast slumps }\end{array}$ \\
\hline Customers & $\begin{array}{l}\text { Individual and } \\
\text { business clients }\end{array}$ & $\begin{array}{l}\text { Machine building } \\
\text { companies }\end{array}$ & $\begin{array}{l}\text { Metal processing } \\
\text { companies }\end{array}$ & $\begin{array}{l}\text { Retailers and } \\
\text { resellers }\end{array}$ \\
\hline $\begin{array}{l}\text { Products and } \\
\text { services }\end{array}$ & $\begin{array}{l}\text { Insurance products, } \\
\text { financial services }\end{array}$ & $\begin{array}{l}\text { Hydraulic cylinder, } \\
\text { job orders }\end{array}$ & $\begin{array}{l}\text { Gear hobbing } \\
\text { machines }\end{array}$ & ICT products \\
\hline
\end{tabular}


Information technologies mentioned in Table 2 refer to ERP, product data management, warehouse management, or collaborative portal solutions. Important is the availability of data collection techniques. The infrastructure includes a low to medium specialized technical equipment. Human resources are specialists and executive staff organized in problem-oriented communication hierarchies. Customer relations are business-to-business and business-to-customer. The organizations offer specialized products or services in different price segments with a medium to high complexity. They have heterogeneous configurations and consist of sophisticated features. The environment is characterized by competitive pressure and changing conditions in regional and international distribution areas. External factors are the behaviour of suppliers, partners, or associated companies. Strategies of the studied organizations include specialization, diversification, quality excellence, flexibility, velocity, and customer orientation.

\subsection{Research cycle 3: Logical application design of OpBI systems}

Machine tool manufacturer. The OpBI system supports the budgeting and scheduling of modernization projects. Data gathering happens manually due to the heterogeneity of working activities. A tracking system records the corresponding working times. The database design (cf. Figure 3) points out expenses for performing the value activities on different levels of detail. Planning and management of project workflows happen simultaneously. Current states of a machine, incurred costs, spent working times, and delivery progress of needed assemblies are demonstrated.

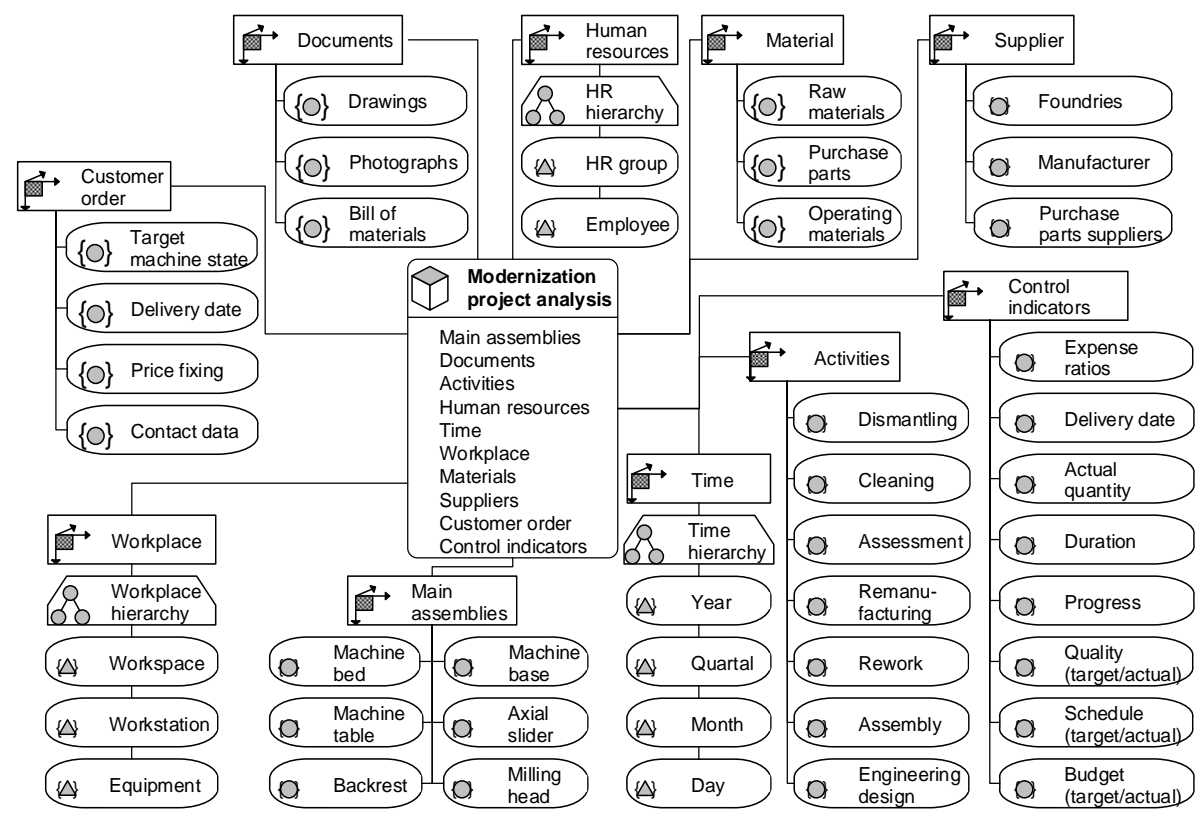

Fig. 3. ADAPT model of a machine tool manufacturer 
A comparison of actual performances to target indicators enables staff to intervene in case of deviations. The procurement combines supplier information with required rework orders and the quality of finished parts. This rating of providers eases a selection for similar constructed parts. The restored machine features of the individual overhaul projects are comparable so that cost estimations become more confident.

ICT Service provider. The OpBI system evaluates cost transparency and efficiency to react fast and flexibly on changing order quantities. The affected IT systems are an ERP and a warehouse management system. The data collection occurs with scanners, light barriers, and a machine time tracking. The designed OpBI database provides a basis to derive management actions for an adjustment of order cycles according to product groups. The consequence is a coordination of logistical cost and productspecific price slumps. The data model facilitates a combination of production batches with similar or equal features to improve processing times. Faced by staff changes, performance targets are determined according to human resource groups. These targets depend on product groups and periods of employment. The calculation of product-specific delivery times leads to higher planning reliability as consequence of specifiable agreements for repair services in context of an outsourced repair service.

Hydraulics engineering company. The OpBI system determines a value added of manufacturing activities and cost ratios of quality issues. The underlying IT systems refer to an ERP system with integrated data acquisition. Terminals collect production data using card readers and barcode scanners. A quality assurance tool collects internal quality complaints. The logical designed database supports an incremental accretion measurement of components and products during manufacturing and assembly. This ensures a constant review of value creation targets. Differences will lead to immediate decisions. A consideration of expenses to create specific features improves the employment of resources, materials, and technologies. Constructors get information to determine prices for new products or add-ons during the design phase based on needed product features. The quality assurance derives actions by costs-bycause principles using the different process perspectives. The logical model enables a calculation of expenses for rework, sorting, or scrap for internal quality complaints.

Insurance agency. The OpBI system combines information of more than 1,800 customers with allocated service tasks. A platform for proposal preparation, policy issues, portfolio management, and accounting supports semi-standardized information records. Sales representatives or office employees enter this information manually. The OpBI's data model considers reasons for unsuccessful approaches to agree conversations. For example, holidays or shift work lead often to calls at inconvenient customer situations. The scheduling is managed according to reachability of customers, now, and appointments are located in nearby sales regions to reduce travel cost. The data model supports a customer-specific control of claim handling to achieve a well-founded settlement. This depends on extent of loss or damage, underlying insurance contracts, and customer behaviour. The agency monitors deadlines for claim review to accelerate handling times. It is measurable whether a 
customer has already reported claim information and how far the reports coincide. A comparison of monthly premiums with a number of contracts per customer leads to a prioritization of claims or a consideration of goodwill. This is beneficial to decide about win-back actions in notice management, too.

\subsection{Lessons learned}

The action research cycles demonstrate methodological and organizational issues to design OpBI database systems based on value-based business requirements. This delivers insights on measuring and evaluating the performance of business processes in four business scenarios. The conjoint reflection of business models, business processes, and IT systems has proven to be advantageous. Valuable results were achieved in all four organizational settings despite of different situational characteristics. Figure 4 repeats the relation between the perspectives of our approach.

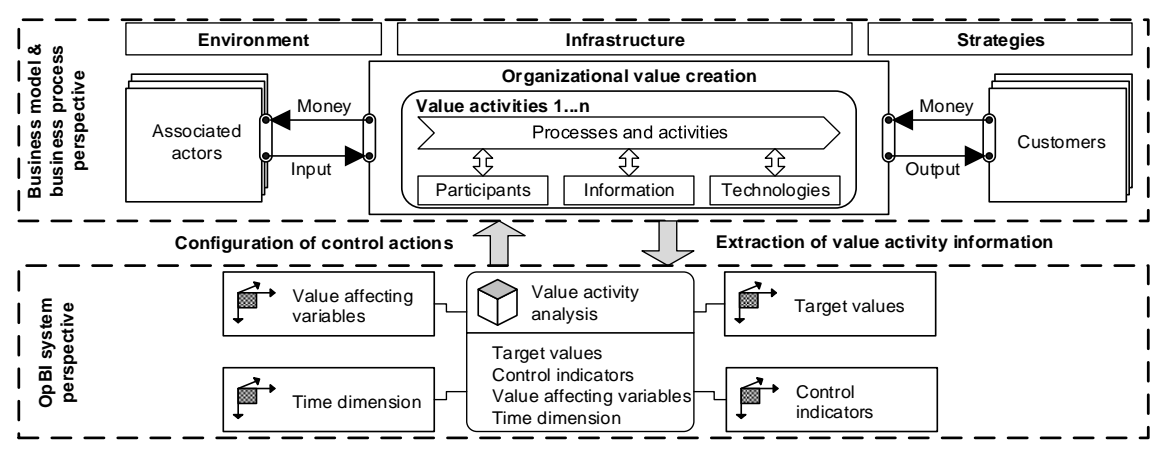

Fig. 4. Relation of business model, business process, and OpBI system perspective

The joined elements of $\mathrm{e}^{3}$ value and work systems are linking an organization's strategy with the maintenance of performant business processes. The association to OpBI is represented at the bottom of Figure 4. ADAPT models are instruments to collect, elaborate, and analyse data about business processes and build the basis to configure management actions. An important aspect learned from our research is the context-sensitive enrichment of these common descriptive perspectives (cf. Table 3).

Tab. 3. Firm-specific and common aspects of our results

\begin{tabular}{|l|ll|}
\hline \multicolumn{1}{|c|}{ Firm-specific aspects } & \multicolumn{1}{c|}{ Common aspects } \\
\hline - Business contexts and strategies & - Methodological building blocks \\
- Business process descriptions & - Action research cycles \\
- Performance management situations & - Collaboration of research and practice \\
- OpBI database designs & - Business process orientation \\
- Management control actions & - Use of operational IT systems \\
\hline
\end{tabular}

The linkage of OpBI with firm-specific business requirements is irreducible complex by observational research methods, because it is necessary to involve situated and practical knowledge resulting from collaboration activities between researchers and 
practitioners. Participatory action research enables such a reference to practical contexts. Implications concerning a performance management of business processes depend thereby always on specific organizations. However, our conceptual findings allow a broader consensus on modelling OpBI systems, although they are not object of a rigorous generalization. Especially the work system framework helped us to learn about common aspects like operational IT systems and repeatable business processes.

\section{Conclusion}

OpBI will support the management of performant business processes, if the analytical concerns are in concurrence to the business requirements of an organization. The paper's contribution enhances a discussion about conceptual aspects of linking OpBI systems design with value-based business requirements. We developed and applied a management approach in coherent action research cycles to provide a conceptual basis for designing OpBI systems from a business perspective.

The paper's arguments shift the discussion about an operational decision-making from technical aspects to a consideration of business strategies. Such a view on information systems is in line with contributions about the impact of IT on business process performance [2]. The novel conceptual approach of value modelling, work system analysis, and analytical design is relevant for application developers and business operation's managers. This supports a definition and evaluation of requirements for an operational decision-making in an organization's business context. The gained conceptual and practical experience from our action research project refers to four different business scenarios. The collaboration of researchers and practitioners has produced a valid conceptual approach and meaningful outcomes in practical contexts. One learning effect is that a consideration of such collaborative efforts leads to firm-specific implications and to reproducible conceptual insights.

This paper builds its evidence on action research, so that its findings and implications have a qualitative nature. The investigated organizations represent typical scenarios of manufacturing and service provision. This indicates a certain resilience of the action research method and is intercessional for a confident replication logic in additional business scenarios. Upcoming research activities should therefore further consolidate conceptual considerations about the integration of analytical concerns and business value perspectives. This allows taking charge of changing analytical technologies and digital opportunities based on a given business logic or value constellation.

\section{References}

1. Blasini, J.: Critical Success Factors Of Process Performance Management Systems: Results Of An Empirical Research. In: 21st European Conference on Information Systems, Utrecht, paper 158, 1-12 (2013)

2. Trkman, P.: The critical success factors of business process management. International Journal of Information Management 30, 125-134 (2010) 
3. Vukšić, V.B., Bach, M.P., Popovič, A.: Supporting performance management with business process management and business intelligence: A case analysis of integration and orchestration. International Journal of Information Management 33, 613-619 (2013)

4. Davis, J., Imhoff, C., White, C.: Operational Business Intelligence: The State of the Art. Beye NETWORK Research, Boulder (2009)

5. Hänel, T., Felden, C.: Towards a Stability of Process Oriented Decision Support Concepts Using the Example of Operational Business Intelligence. In: Pre-ICIS BI Congress 3: Driving Innovation through Big Data Analytics, Orlando (2010)

6. Gordijn, J., Akkermans, H.: Value Based Requirements Engineering: Exploring Innovative e-Commerce Ideas. Requirements Engineering Journal 8, 114-134 (2002)

7. McAfee, A., Brynjolfsson, E.: Big Data: The Management Revolution. Harvard Business Review, 90, 60-66 (2012)

8. Juan-Verdejo, A., Baars, H.: Decision support for partially moving applications to the cloud: the example of business intelligence. In: International Workshop on Hot Topics in Cloud Services, New York, 35-42 (2012)

9. Plattner, H.: A Common Database Approach for OLTP and OLAP Using an In-Memory Column Database. In: ACM SIGMOD International Conference on Management of data, Providence, 1-2 (2009)

10. Van der Lans, R.: Data Virtualization for Business Intelligence Systems: Revolutionizing Data Integration for Data Warehouses. Morgan Kaufmann, Waltham (2012)

11. MIS Journal Rankings, http://aisnet.org/?JournalRankings

12. Cunningham, D.: Aligning Business Intelligence with Business Processes. What Works 20, 50-51 (2005)

13. Otley, D.: Performance Management: A Framework for Management Control Systems Research. Management Accounting Research 10, 363-382 (1999)

14. Kueng, P., Krahn, A.: Building a Process Performance Measurement System: some early experiences. Journal of Scientific \& Industrial Research 58, 149-159 (1999)

15. Janiesch, C., Matzner, M., Müller, O.: Beyond process monitoring: a proof-of-concept of event-driven business activity management. Business Process Management Journal 18, 625-643 (2012)

16. van der Aalst, W.M.P.: Process Mining: Discovery, Conformance and Enhancement of Business Processes. Springer Publishing Company, Berlin (2011)

17. Kang, B., Kim, D., Kang, S.H.: Periodic performance prediction for realtime business process monitoring. Industrial Management and Data Systems, 112, 4-23 (2012)

18. Cheung, M., Hidders, J.: Round-trip iterative business process modelling between BPA and BPMS tools. Business Process Management Journal 17, 461-494 (2011)

19. Felden, C., Chamoni P., Linden, M.: From Process Execution towards a Business Process Intelligence. In: 13th International Conference on Business Information Systems, Berlin, 195-206 (2010)

20. Bucher, T., Gericke, A., Sigg, S.: Process-centric business intelligence. Business Process Management Journal 15, 408-429 (2009)

21. Baskerville, R.L.: Investigating Information Systems with Action Research. Communications of AIS 2, 1-32 (1999)

22. Breu, K., Peppard, J.: The Participatory Paradigm for Applied Information Systems Research. In: 9th European Conference on Information Systems, Bled, 243-252 (2001)

23. Alter, S.: Work System Theory: Overview of Core Concepts, Extensions, and Challenges for the Future. Journal of the Association for Information Systems 14, 72-121 (2013)

24. Getting Started with ADAPT, http://www.symcorp.com/downloads/ADAPT_white _paper.pdf 